\title{
Presence of Several Plasmids in the Fungus Ascobolus immersus, and Homologies with the Linear Plasmid pA1
}

\author{
By FRANÇOIS-XAVIER FRANCOU, ${ }^{1}$ NEEL RANDSCHOLT, ${ }^{2}$ \\ BERNARD DECARIS ${ }^{3}$ * AND ANNIE GREGOIRE ${ }^{1}$ \\ ${ }^{1}$ Laboratoire de Biologie Expérimentale, Université de Paris XI, Bâtiment 400, \\ 91405 Orsay Cedex, France \\ ${ }^{2}$ Centre de Génétique Moleculaire du CNRS, 91190 Gif sur Yvette, France \\ ${ }^{3}$ Laboratoire de Génétique et Microbiologie, Université de Nancy I, BP 239, \\ 54506 Vandoeuvre les Nancy Cedex, France
}

(Received 29 April 1986; revised 16 September 1986)

\begin{abstract}
DNA analysis of several genetically unstable strains of the fungus Ascobolus immersus revealed the presence of at least seven different plasmids. These plasmids ranged from 2 to $20 \mathrm{~kb}$ in size, and showed homology to one of them, pAl. In 18 stocks directly isolated from nature, two-thirds harboured plasmids ranging from 3 to $17 \mathrm{~kb}$. Plasmids with homology to pAl had similar molecular masses (about $8.5 \mathrm{~kb}$ ). A possible mechanism of plasmid formation from chromosomal DNA is discussed.
\end{abstract}

\section{INTRODUCTION}

In recent years, genetic studies of the filamentous ascomycete Ascobolus immersus have taken two main directions: the first concerns genetic recombination and conversion (Rossignol et al., 1984); the second centres on a genetic instability system affecting many genes throughout the genome (Decaris et al., 1980). Genetic analyses have indicated that the instability phenomenon is due to a mobile element inserted at the unstable site. Several biological characteristics of such elements are known. The first concerns genomic rearrangements, the second modifications of gene expression - inhibition (integration) and recovery of normal function (excision) - caused by these elements. Excision, controlled by at least one gene of the putative transposon, takes place during well-defined stages of the cellular differentiation cycle. Thus, several different excision systems have been described, each defined by the stage of the cell cycle at which they take place.

In both major $A$. immersus research domains, genetic studies are carried out by using ascospore mutants that allow an extremely fine genetical analysis, but a molecular approach has now become necessary to complete the genetical data. The study of genetic instability led us to search for hypothetical free mobile elements. We demonstrated the existence of a linear DNA plasmid in the unstable strains (Francou, 1981). The plasmid molecule pAl is $6 \mathrm{~kb}$ long, with $1.2 \mathrm{~kb}$ terminal inverted repeated sequences. It has a transposon-like structure and might even be a free transposon. Some wild-type strains do not contain pA1. This allowed us to show by reciprocal crosses that the genetic instability of mutant strains could exist in the absence of plasmids. These results raised two questions. (a) Do all the strains related to the unstable strain (stock 50) contain the same plasmid? (b) Do other wild-type strains, of different geographical origins, contain this plasmid?

Our study based on genetic variability could also provide an opening towards the use of autonomous transformation vectors in filamentous fungi. All transformation systems developed to date for these fungi involve integration into chromosomal DNA (Brygoo \& Debuchy, 1985), even though certain vectors used contain a fragment of a mitochondrial plasmid (Kuiper \& de Vries, 1985). The plasmid pA1 is maternally inherited, which indicates that it is maintained 
through extrachromosomal replication. Thus the use of natural plasmids might prove an interesting way to solve the problem of maintaining plasmids in the free form in filamentous fungi. The use of the $2 \mu$ plasmid in transformation vectors for its natural host yeast, Saccharomyces cerevisiae (Guerineau, 1979), came about in much the same manner.

\section{METHODS}

Strains of Ascobolus immersus. A stock is defined as the progeny from a cross between two strains arising from two ascospores of the same ascus isolated from nature.

(a) Unstable stocks. All unstable strains were the progeny of a cross between two strains (now lost) isolated from nature (stock 50).

Strains 37.32 and 37.30 were obtained from the progeny of the cross between the original strains.

Strain 87.13 carried the b10.B mutation, in a gene controlling spore colouration. This unstable allele was spontaneously isolated from the progeny of the first cross and the strain was isolated from the third backcross between mutant and wild-type or revertant strains.

Strain 260.100 was a killer-like strain isolated from an ascus with four normal and four non-viable spores. The progeny of this strain was four-spored. It was obtained by crossing two revertant strains.

Strain 375.8 was Met $^{-}$. This mutation was suppressible by adding $O$-acetylhomoserine to the growth medium and may correspond to the met-2 gene of $S$. cerevisiae. This mutant appeared spontaneously in the progeny of revertant strains.

(b) Other stocks. With the exception of stock 28, used for the recombination study (Rossignol et al., 1984), the 18 stocks were isolated from nature by G. Rizet and A. Collard. Two ascus types were found. One was normal with eight wild-type ascospores, and strains were randomly picked (stocks $23,29,30,52,60,61,65,69,75,109,115,119$, 140,141 and 154). The second type contained four normal and four non-viable spores (stocks 41, 85, 124 and 154). These stocks, as well as stock 28 , were represented by one strain.

Escherichia coli strain. For the molecular cloning of $\mathrm{pA}$, we used as host strain $E$. coli $\mathrm{BJ} 5183: \mathrm{Hsp}^{-} \mathrm{Gal}^{-} \mathrm{Met}^{-}$ $\mathrm{Bio}^{-} \mathrm{RecBC}^{-}$SbeA- $\operatorname{Str} \mathrm{A}^{-}$.

DNA extraction. Mycelium culture, total DNA extraction and plasmid DNA purification were as previously described (Francou, 1981). The plasmid extraction procedure permits isolation of all plasmids, whatever their size or density, as long as their molecular mass is sufficiently low $(\leqslant 10 \mathrm{~kb})$, and the material is sufficiently abundant (at least $0.1 \%$ of the total DNA). Extraction experiments without protease always yielded less plasmid material. This could point to the presence of proteins covalently linked to the plasmid DNA, as is the case for other linear molecules (Rekosh et al., 1977; Erickson et al., 1985; Stillman, 1983; Hirochika \& Sakaguchi, 1982). The preparative electrophoresis technique also permits the isolation of linear molecules unobtainable from caesium chloride/ethidium bromide gradients.

Cloning of pA1. All cloning techniques (restriction enzyme digestions, ligations, transformation of bacteria, etc.) were according to Maniatis et al. (1982). The location of the HpaII sites on pAl (Francou, 1981) allowed the insertion at the pBR $322 \mathrm{ClaI}$ site of a $3.2 \mathrm{~kb}$ DNA fragment from pAl containing most of the plasmid's unique sequence plus nine-tenths of one of the terminal repeats. This recombinant plasmid makes up a probe without chromosomal DNA representing almost all of pAl.

Hybridization. DNA was transferred to nitrocellulose (Southern,1975) and hybridized to a probe labelled with ${ }^{32} \mathrm{P}$ by nick translation (Rigby et al., 1977). The molecular mass marker, HindIII-digested $\lambda$ DNA, was also labelled with ${ }^{32} \mathrm{P}$ and added to the probe. The blots were incubated overnight at $65^{\circ} \mathrm{C}$ in $5 \times$ Denhardt's solution (Denhardt, 1966), $2 \times$ SSC (SSC is $0.15 \mathrm{M}-\mathrm{NaCl} / 0.015 \mathrm{M}$-trisodium citrate, $\mathrm{pH} 7.0$ ) and $10 \mu \mathrm{g}$ heat-denaturated calf thymus DNA ml ${ }^{-1}$. This solution was then replaced by $10 \%(\mathrm{w} / \mathrm{v})$ dextran sulphate (Wahl et al., 1979) in $2 \times$ SSC to which the heat-denatured probe was added. Filters were washed at $65^{\circ} \mathrm{C}$ in $2 \times \operatorname{SSC} / 0.1 \%$ SDS. Autoradiograms (Kodak X-Omat S) were exposed at $-70^{\circ} \mathrm{C}$

\section{RESULTS}

\section{Plasmids revealed by electrophoresis}

Stock 50. All the strains from stock 50 contained one or more plasmids visible on gels (Fig. $1 a$ ). Some of them existed in very small amounts frequently undetectable on the gels. This was true for the $3 \mathrm{~kb}$ plasmid in strain 260.100 . We noted different plasmid patterns in genetically closely related strains. The plasmids are listed in Table 1.

Wild-type strains. These were divisible into two classes, with and without plasmids. Plasmid sizes ranged between 3 and $17 \mathrm{~kb}$ (Fig. $2 a$, Table 1). The low-molecular-mass plasmids were difficult to visualize on prints of the gels (Fig. 2a, lane 5). Stocks 61 and 124 contained two and three plasmids, respectively. 

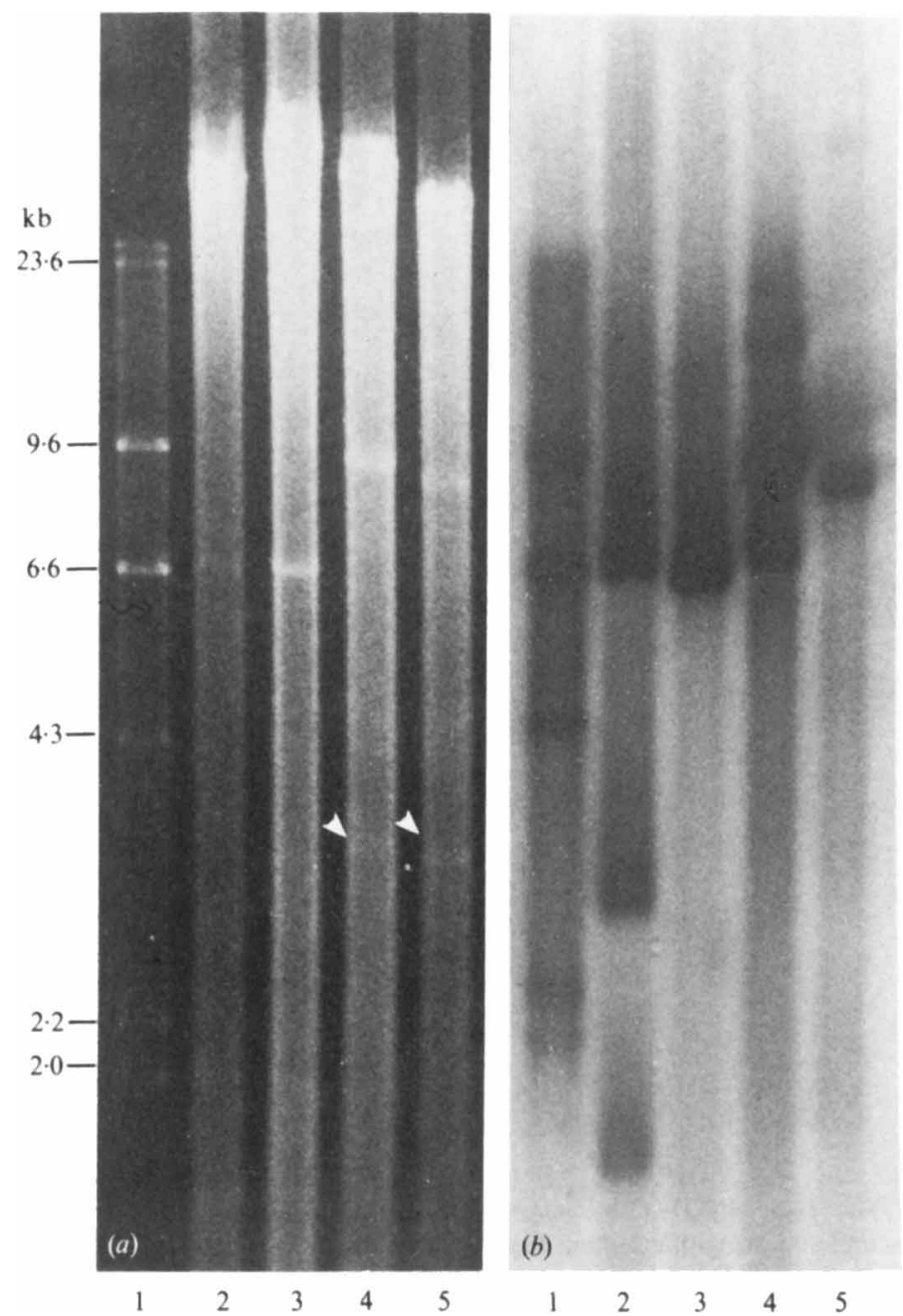

Fig. 1. (a) DNA from different strains of stock 50 was separated by electrophoresis and stained with ethidium bromide. The arrowheads indicate the positions of plasmids found in small amounts. (b) DNA from the gel in (a) was blotted onto nitrocellulose and hybridized to $\mathrm{pAl}$ and $\lambda$ labelled with ${ }^{32} \mathrm{P}$. Lanes: 1, $\lambda$ DNA digested with HindIII; 2, strain $37.32 ; 3$, strain $87.13 ; 4$, strain $260.100 ; 5$, strain 375.8 .

\section{Homology to plasmid pAI}

Stock 50. Hybridization to the probe containing pAl showed the presence of a third plasmid in strains 37.32 and 37.30 (Fig. 1 b). It was shorter than $2 \mathrm{~kb}$ and undetectable by ethidium bromide staining. All the strains analysed from stock 50 harboured at least one plasmid hybridizing to pAl.

Wild-type strains. The hybridizations are shown in Fig. 2(b) (see also Table 1). Plasmids hybridizing to pAl were about $8.5 \mathrm{~kb}$ in size. Two exceptions, in stocks 109 and 115 (Fig. $2 b$, lanes 8 and 9), may correspond to dimers and/or some intermediate structures. Stock 61 contained two types of plasmids, one $(8.5 \mathrm{~kb})$ homologous to $\mathrm{pAl}$ and a second $(3 \mathrm{~kb})$ which did not hybridize. This also occurred in strains 260.100 and 375.8 from stock 50 . The strains classified as plasmid-free by electrophoretic analysis did not reveal any plasmid hybridizing to pAl (data not shown). 

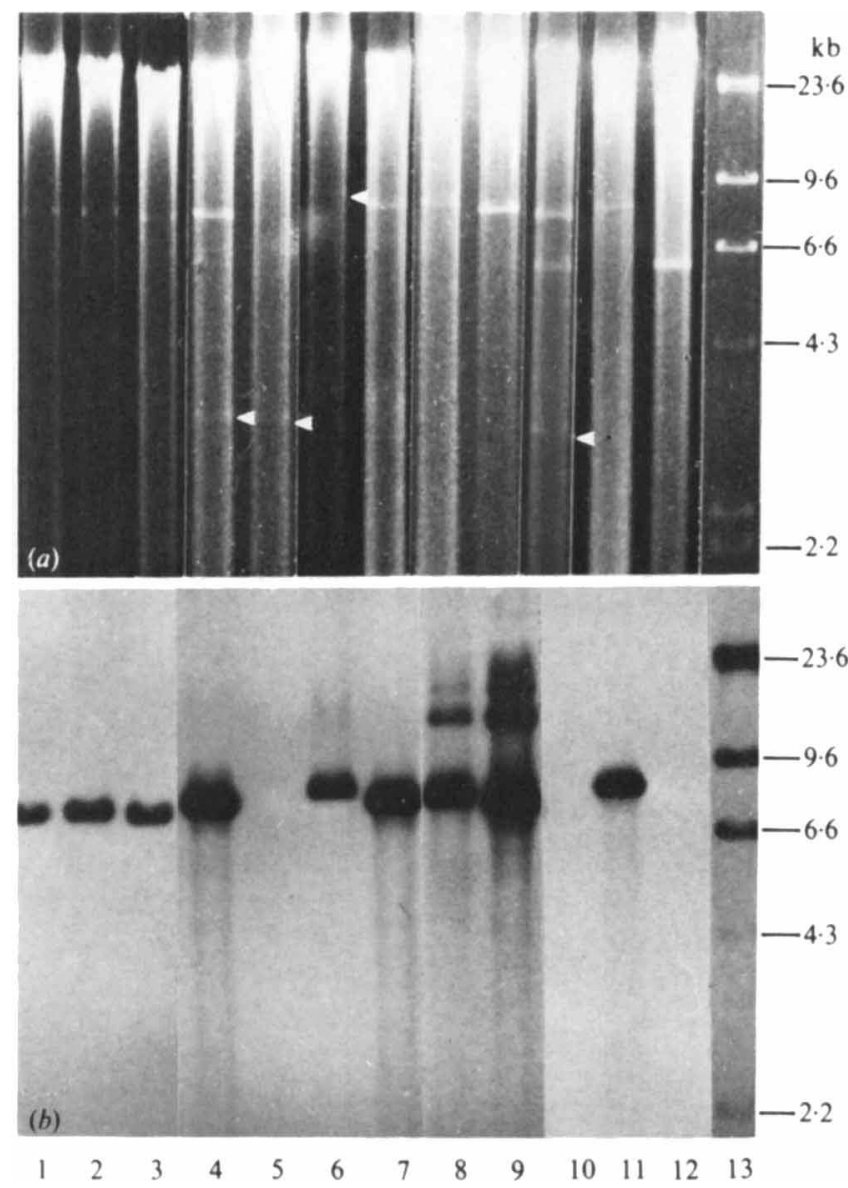

Fig. 2. (a) DNA from different $A$. immersus strains containing plasmids was separated by electrophoresis and stained with ethidium bromide. Arrowheads indicate the positions of plasmids found in small amounts. (b) DNA from the gel in (a) was blotted onto nitrocellulose and hybridized to pAl or $\lambda$ labelled with ${ }^{32} \mathrm{P}$. Lanes: 1 , stock $30 ; 2$, stock $41 ; 3$, stock $52 ; 4$, stock $61 ; 5$, stock $65 ; 6$, stock $69 ; 7$, stock $75 ; 8$, stock $109 ; 9$, stock $115 ; 10$, stock $124 ; 11$, stock $141 ; 12$, stock $154 ; 13, \lambda$ DNA digested with HindIII.

\section{DISCUSSION}

Analysis of DNA from $A$. immersus strains of different geographical origins shows that this fungus often contains plasmids. We found such molecules in about two-thirds of the strains directly isolated from nature. A high frequency of occurrence of $2 \mu$ plasmids in Saccharomyces (Gunge et al., 1981) has already been observed.

Stock 50 strains contained a number of different plasmids with sizes ranging from 2 to $20 \mathrm{~kb}$, and the plasmids homologous to $\mathrm{pAl}$ also had sizes between 2 and $20 \mathrm{~kb}$. In other strains, while numerous plasmids of different sizes were found, most of those which hybridized to pAl were close to $8.5 \mathrm{~kb}$ in size, except for stocks 109 and 115 , where the large molecules homologous to pAl may correspond to multimers.

All different subcultures of the same strain always showed the same plasmid pattern. But in different strains from stock 50 , plasmid patterns sometimes differed. This variability was found over a limited number of sexual generations - less than ten. Thus three plasmids were harboured in the parental strains (37.30 and 37.32) and two of them had disappeared in the case of one strain of the progeny (strain 87.13 ). Moreover, in strain 260.100 , derived from the same parental strains ( 37.30 and 37.32 ), at least two new molecular types had appeared. In a third strain of the 
Table 1. Plasmids detected in A. immersus

Stocks $23,28,29,60,85,119$ and 140 contained no detectable plasmids

\begin{tabular}{ccl} 
Stock & Strain & \multicolumn{1}{c}{ Plasmids (kb) } \\
50 & 37.30 & $6 \cdot 5^{*}, 3^{*}, 1 \cdot 8^{*}$ \\
& 37.32 & $6.5^{*}, 3^{*}, 1 \cdot 8^{*}$ \\
& 87.13 & pA1 \\
& 260.100 & $20^{*}, 10^{*}, 7 \cdot 5^{*}, 3$ \\
30 & 375.8 & $10^{*}, 3$ \\
41 & & $8 \cdot 5^{*}$ \\
52 & & $8 \cdot 5^{*}$ \\
61 & & $8 \cdot 5^{*}$ \\
65 & & $8 \cdot 5^{*}, 3$ \\
69 & & 3 \\
75 & & $8 \cdot 5^{*}$ \\
109 & & $8 \cdot 5^{*}$ \\
115 & & $17^{*}, 8 \cdot 5^{*}$ \\
124 & & $17^{*}, 8 \cdot 5^{*}$ \\
141 & & $8 \cdot 5,6 \cdot 5,3$ \\
154 & & $8 \cdot 5^{*}$ \\
& & $6 \cdot 4$ \\
& & \\
& &
\end{tabular}

progeny (strain 375.8), the original plasmids had disappeared and were replaced by two new molecules, one of which had no homology to the reference plasmid pA1.

The frequent occurrence of plasmids in $A$. immersus raises the question of their function. We were unable to make any correlation in any of the strains studied here between the presence of one or several plasmids and a given phenotype. Only the killer-like characteristic may possibly be correlated to the presence of a plasmid, as described in Kluyveromyces lactis (Wesolowski et al., 1982). But stock 85, which has the killer-like phenotype, contains no detectable plasmid. This situation resembles a phenomenon found in Neurospora where a chromosomal factor located on linkage group III causes death at meiosis of all products devoid of that factor (Turner \& Perkins, 1979). For the three other killer-like stocks $(41,124$ and 154) our data are still incomplete.

The results also raise the problem of the origin of the plasmids in stock 50 . The simplest hypothesis may be the existence of pAl sequences integrated into the chromosome which could, by some unknown mechanism, be excised along with a small or large fragment of the DNA flanking the insertion site. This hypothesis is reinforced by the observation of slight hybridization of the pAl fragment with chromosomal DNA (unpublished results). Maintaining free plasmid molecules from one generation to the next presupposes the existence of a replication system (origin, control, etc) (Brygoo \& Debuchy, 1985). The loss of certain plasmids, and the generation of plasmids of different sizes, may be due to replication errors. Such excision and/or insertion mechanisms of an autonomous sequence from a complex replicon have been described in numerous prokaryotic and eukaryotic organisms. In prokaryotes, the clearest examples are found in Streptomyces (Bibb et al., 1981; Omer \& Cohen, 1981; Pernodet et al., 1984). Plasmids generated in such a way are made up of two parts, one constant and the other variable. In this case, insertion into the chromosome is site-specific.

The existence of plasmids homologous to $\mathrm{pAl}$ in about $50 \%$ of wild-type strains from different origins points to a wide distribution of this DNA sequence in $A$. immersus. The ability of stock 50 to generate different plasmids may result from excision of sequences integrated into the nuclear chromosomes before the strain was isolated. This raises the question of the reciprocal mechanism: can these plasmids be integrated into the chromosome, and is this kind of integration event the origin of these sequences in $A$. immersus?

This work was supported by grants from Université Paris Sud, from the Centre National de la Recherche Scientifique (LA no. 86) and from the Ministère de la Recherche et de la Technologie (ATP Biotechnologie). 


\section{REFERENCES}

Bibb, M. J., WARD, J. M., Kieser, T., COHEN, S. N. \& HOPWOOD, D. A. (1981). Excision of chromosomal DNA sequences from Streptomyces coelicolor forms a novel family of plasmids detectable in Streptomyces lividans. Molecular and General Genetics 184, 230240.

BRYGOO, Y. \& DEBUCHY, R. (1985). Transformation by integration in Podospora anserina. I. Methodology and phenomenology. Molecular and General Genetics 200, 128-131.

Decaris, B., Francou, F., Kouassi, A., Lefort, C. \& RizeT, G. (1980). Genetic instability in Ascobolus immersus: modalities of back-mutations, intragenic mapping or unstable sites and unstable insertion. Preliminary biochemical data. Cold Spring Harbor Symposia on Quantitative Biology 45, 509-517.

DENHARDT, D. T. (1966). A membrane filter technique for the detection of complementary DNA. Biochemical and Biophysical Research Communications 23, 641-646.

Erickson, L., Beversdorf, W. D. \& Pauls, K. P. (1985). Linear mitochondrial plasmid in Brassica has terminal protein. Current Genetics 9, 679-682.

FRANCOU, F. (1981). Isolation and characterization of a linear DNA molecule in the fungus Ascobolus immersus. Molecular and General Genetics 184, 440-444.

GuERINEAU, M. (1979). Plasmid DNA in yeast. In Viruses and Plasmids in Fungi, vol. 1, pp. 539-593. Edited by P. A. Lemke. New York \& Basel: Marcel Dekker.

Gunge, N., Tamaru, A., Ozawa, F. \& Sakaguchi, K. (1981). Isolation and characterization of linear deoxyribonucleic acid plasmids from Kluyveromyces lactis and the plasmid associated killer character. Journal of Bacteriology 145, 382-390.

HiRochIKa, H. \& SAKaGUCHI, K. (1982). Analysis of linear plasmids isolated from Streptomyces: association of protein with the ends of the plasmid DNA. Plasmid 7, 59-65.

KUIPER, M. T. R. \& DE VRIES, H. (1985). A recombinant plasmid carrying the mitochondrial plasmid sequence of Neurospora intermedia laBelle yields new plasmid derivatives in Neurospora crassa transformants. Current Genetics 9, 471-477.
MANiatis, T., Fritsch, E. F. \& SAMbrooK, J. (1982). Molecular Cloning: A Laboratory Manual. Cold Spring Harbor, NY: Cold Spring Harbor Laboratory.

OMER, C. A. \& COHEN, S. N. (1984). Plasmid formation in Streptomyces: excision and integration of the $\mathrm{SLP}_{1}$ replicon at a specific chromosomal site. Molecular and General Genetics 196, 429-438.

Pernodet, J. L., Simonet, J. M. \& Guerineau, M. (1984). Plasmids in different strains of Streptomyces ambofaciens: free and integrated form of plasmid pSAM2. Molecular and General Genetics 198, 35-41.

ReKosh, D. M. K., Russell, W. C., Bellet, A. J. D. \& RoBINSON, A. J. (1977). Identification of a protein linked to the ends of adenovirus DNA. Cell 11, 283295.

Rigby, P., Dieckmann, M., Rhodes, C. \& Berg, P. (1977). Labelling deoxyribonucleic acid to high specific activity in vitro by nick translation with DNA polymerase I. Journal of Molecular Biology 113, 237-251.

Rossignol, J. L., Nicolas, A., Hamza, H. \& Langin, T. (1984). Origins of gene conversion and reciprocal exchange in Ascobolus. Cold Spring Harbor Symposia on Quantitative Biology 49, 13-21.

SoUTHERN, E. (1975). Detection of specific sequences among DNA fragments separated by gel electrophoresis. Journal of Molecular Biology 98, 503-517.

StILlmaN, B. W. (1983). The replication of adenovirus DNA with purified protein. Cell 35, 7-9.

TURner, B. C. \& Perkins, D. D. (1979). Spore killer, a chromosomal factor in Neurospora that kills meiotic products not containing it. Genetics 93, 587-606.

Wahl, G. M., Stern, M. \& Stark, G. R. (1979). Efficient transfer of large DNA fragments from agarose gels to diazobenzyloxy methyl paper and rapid hybridization by using dextran sulfate. Proceedings of the National Academy of Sciences of the United States of America 76, 3683-3687.

Wesolowski, M., Algeri, P., Gossrini, P. \& FukUHARA, H. (1982). Killer DNA plasmids of the yeast Klyveromyces lactis. I. Mutations affecting the killer phenotype. Current Genetics 5, 191-198. 